\title{
Bibliografia prac Wojciecha Stawiszyńskiego
}

\section{Bibliografie}

Bibliografia patrystyczna 1901-2004. Polskie thumaczenia tekstów starochrześcijańskich pierwszego tysiaclecia, Kraków 2005.

Bibliografia patrystyczna 1901-2016. Polskie thmaczenia tekstów starochrześcijańskich pierwszego tysiaclecia, wydanie trzecie, rozszerzone, poprawione i zmienione, Kraków 2017.

Bibliografia polskich tłumaczeń tekstów gnostyckich, hermetycznych i manichejskich oraz polemistów chrześcijańskich i katalogów herezji, w: Tajemnice gnozy: VI kodeks biblioteki z Nag Hammadi - inny niż wszystkie, red. A. Sowińska - W. Stawiszyński, Warszawa 2016, s. 193-225.

Kopp E. - Stawiszyński W., Bibliografia prac prof. dr hab. Albertyny Szczudłowskiej-Dembskiej, „Vox Patrum” 61 (2014) s. 703-708.

Kopp E. - Stawiszyński W., Bibliografia prac prof. dr hab. Albertyny Szczudłowskiej-Dembskiej, w: Tajemnice gnozy: VI kodeks biblioteki z Nag Hammadi - inny niż wszystkie, red. A. Sowińska - W. Stawiszyński, Warszawa 2016, s. 17-28.

Longosz S. - Stawiszyński W., Św. Augustyn w polskich studiach: materiały bibliograficzne, ,Vox Patrum” 44/45 (2003) s. 521-623.

Polska bibliografia antyku chrześcijańskiego 2017-2019, „Vox Patrum” 74 (2020) s. 231-306.

Polska bibliografia antyku chrześcijańskiego 2019-2020, „Vox Patrum” 78 (2021) s. 517-546.

\section{Redakcje}

Longosz S., Opera Minora Selecta, red. J. Iluk - W. Stawiszyński, Warszawa 2019.

Tajemnice gnozy: VI kodeks biblioteki z Nag Hammadi - inny niż wszystkie. Tom poświęcony pamięci Profesor Albertyny Szczudłowskiej-Dembskiej (1934-2013), red. A. Sowińska - W. Stawiszyński, Warszawa 2016. 


\section{Recenzje}

Atanazy Wielki, Historia arian spisana dla mnichów, wprowadzenie, tłumaczenie, przypisy E. Dusik-Krupa, Kraków 2018, ss. 99 - https://fil.ug.edu.pl/strona/74304/ wojciech_stawiszynski_-_atanazy_wielki_historia_arian_spisana_dla_mnichow_ recenzja (dostęp: 25.07.2021).

Hilman K., Pikus w Kronice aleksandryjskiej i u Malalasa. Narodziny mitu u schytku Antyku, Kraków 2019, ss. 142 - https://fil.ug.edu.pl/strona/99686/wojciech_stawiszynski_-_krzysztof_hilman_pikus_w_kronice_aleksandryjskiej_i_u_malalasa_narodziny_ mitu_u_schylku_antyku_wydawnictwo_uniwersytetu (dostęp: 25.07.2021).

Izydor z Sewilli, Historia Gotów, Wandalów i Swebów oraz kroniki wczesnośredniowiecznej Hiszpanii, przekład, wstęp i opracowanie A. Foryt, Kraków 2017, ss. 179 https://fil.ug.edu.pl/strona/74688/wojciech_stawiszynski_-_izydor_z_sewilli_historia_gotow_wandalow_i_swebow_oraz_kroniki (dostęp: 25.07.2021).

Lewandowicz J.., Klasztory, mnisi, mniszki. Obraz życia monastycznego w „Registrum epistularum” Grzegorza Wielkiego na tle prawa cesarskiego i kościelnego, Kraków 2018, ss. 437 - „Vox Patrum” 70 (2018) s. 758-761.

Nowe odczytanie codzienności. Teksty Wschodnich i Zachodnich Ojców Kościoła. Codzienność widziana $w$ świetle Jezusa Chrystusa $w$ pierwszych wiekach chrześcijaństwa, wybór dokonany przez Wspólnote Monastyczna z Bose (Italia) wedtug rytmu Liturgii Godzin, tłumaczenie z języka włoskiego A. Koprowski SJ, Warszawa 2017, ss. 594 - https://fil.ug.edu.pl/strona/73399/wojciech_stawiszynski_-_nowe_odczytanie_ codziennosci_teksty_wschodnich_i_zachodnich_ojcow_kosciola (dostęp: 25.07.2021).

Pietras H. SJ, Sobór Nicejski (325). Kontekst religijny i polityczny, dokumenty, komentarze, Kraków 2013, ss. 236 - „Vox Patrum” 61 (2014) s. 567-572.

\section{Inne}

In Memoriam: Profesor Albertyna Szczudłowska-Dembska (9 XII 1934 - 17 IX 2013), „Vox Patrum” 61 (2014) s. 701-703.

Profesor Albertyna Szczudłowska-Dembska, w: Tajemnice gnozy: VI kodeks biblioteki z Nag Hammadi - inny niż wszystkie, red. A. Sowińska - W. Stawiszyński, Warszawa 2016, s. 5-10.

Uroczystość nadania doktoratu honoris causa Papieskiego Wydziału Teologicznego w Warszawie Księdzu Profesorowi Markowi Starowieyskiemu (Warszawa, 12 XII 2017), „Vox Patrum” 70 (2018) s. 791-792.

Indeksy, w: Nowy słownik wczesnochrześcijańskiego piśmiennictwa, red. M. Starowieyski - J.M. Szymusiak, Poznań 2018, s. 1033-1087. 